\title{
ERRORS IN THE RADIOCARBON DATING OF DEPOSITS IN FINLAND FROM THE TIME OF DEGLACIATION
}

\author{
J. J. Donner and H. Jungner
}

\begin{abstract}
Donner, J. J. and JUNGNER, H. 1974: Errors in the radiocarbon dating of deposits in Finland from the time of deglaciation. Bull. Geol. Soc. Finland 46, 139-144.
\end{abstract}

\begin{abstract}
Some radiocarbon dates of sediments from the area of the Salpausselkä moraines, and north of them in the area deglaciated after c. 10200 B.P., are too old and at variance with a number of radiocarbon dates for the regional pollen assemblage zones. Redeposited organic material is mainly responsible for the dates being too old, but an influence of the hard-water effect and of graphite can also be demonstrated. The age of the deglaciation is therefore likely to be in agreement with that suggested by the varve chronology and supported by most radiocarbon dates from organic deposits.

J. J. Donner, Department of Geology and Palaeontology, University of Helsinki, SF-00170 Helsinki 17, Finland

H. Jungner, Radiocarbon Dating Laboratory, University of Helsinki, SF-00170 Helsinki 17, Finland.
\end{abstract}

This paper is a modified version of one with the same title presented at the IX INQUA Congress 2-10 December, 1973 , in Christchurch, New Zealand.

In the Finnish varve chronology the zero year, \pm 0 , marks the drainage of the Baltic Ice Lake and a lowering of the water level down to the level of the Yoldia Sea, at the time when the ice margin stood at, or just inside, the Salpausselkä II moraine. All varve measurements in southern Finland have used this same zero year (Fig. 1) and it is through this varve the Finnish chronology has been correlated with the Swedish varve chronology, where the revised date for the drainage of the Baltic Ice Lake is 8213 B.C., c. 10200 B.P. (Nilsson 1968). Fromm (1970) has estimated the magnitude of the possible system- atical errors to a few hundred years. The dating of the two main Salpausselkä moraines by Niemelä (1971) differs somewhat from that by Sauramo (1918, 1923), the difference, however, not being great and not of importance to the present problem. The boundary between the oldest pollen assemblage zones in SE Finland, between the NAP R (SE Finland) P.A.Z. and the Birch R (SE Finland) P.A.Z., has, according to the radiocarbon dates, an age of about 10100 10150 B.P. (Donner 1971) and thus corresponds closely to the Late Weichselian/Flandrian boundary elsewhere in north-western Europe. Deposits 
POLLEN ASSEMBLAGE ZONES (S.E. FINLAND)

Donner 1971
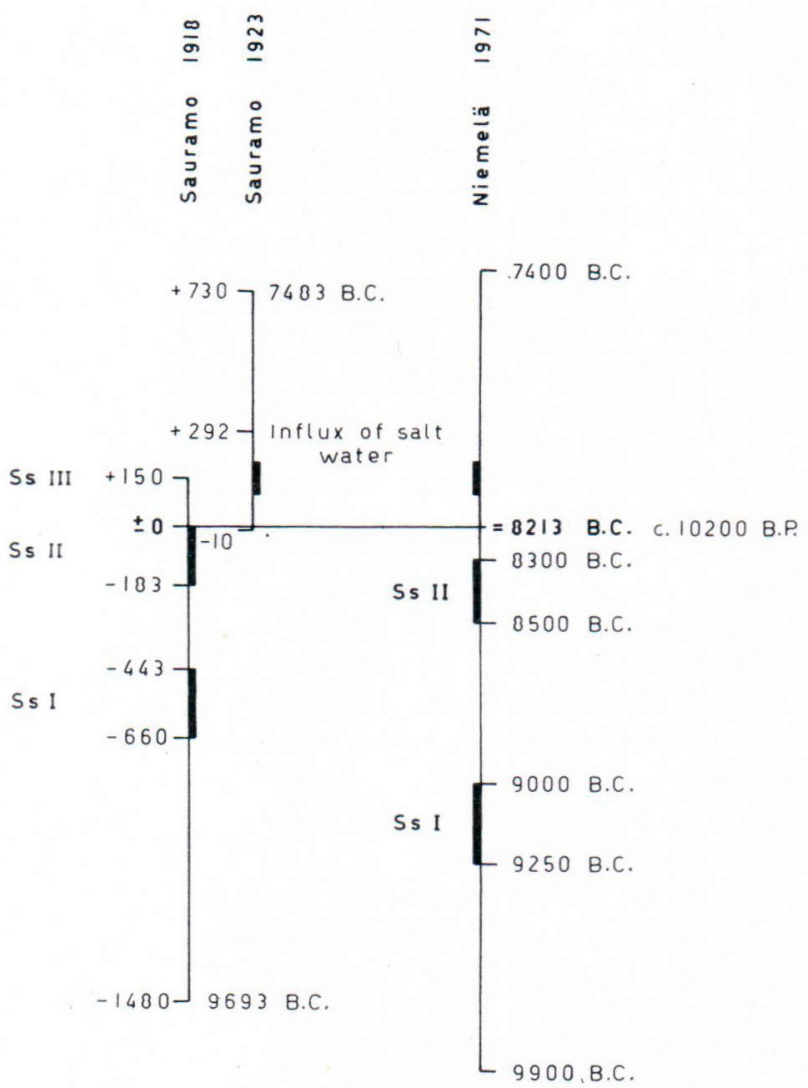

RADIOCARBON

DATES

c. 8900 B.P.

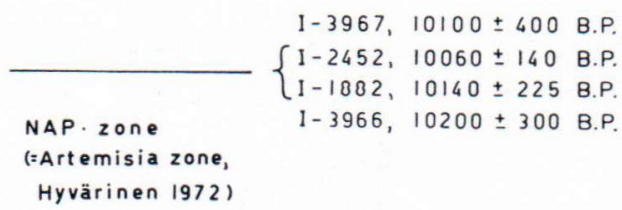

1-3967, $10100 \pm 400$ B.P. $\{1-2452,10060 \pm 140$ B.P. $I-1882,10140 \pm 225$ B.P.

Hyvärinen 1972)

Fig. 1. Varve chronology compared with pollen assemblage zones for SE Finland and radiocarbon dates.

representing the Late Weichselian NAP zone occur especially in SE Finland but not north of the Salpausselkä moraines. There all organic deposits represent the Flandrian assemblage zones, which in many areas have been dated with a number of radiocarbon dates. The distribution of the sediments pollen analytically studied agrees with the varve dating of the deglaciation. Some radiocarbon dates in the area of the Salpausselkä moraines and north of them, in the area deglaciated after c. 10200 B.P., are however too old. They are also at variance with a number of radiocarbon dates used for dating the regional assemblage zones. Instead of supporting argu- ments for an earlier withdrawal of the ice than that suggested by the varve chronology and most of the radiocarbon dates of organic sediments, the old radiocarbon dates in Finland are here interpreted as having been caused by errors in the radiocarbon dating. Fig. 2 shows the dates which are too old and the 8 sites they represent. The continuation of the Salpausselkä II moraine east of the Finnish border is outlined in the map according to morphological and stratigraphical studies in the USSR (see summary by Hyvärinen 1973). In the north the TromsöLyngen moraine is marked, the final phase of its formation being dated at c. 10200 B.P. 


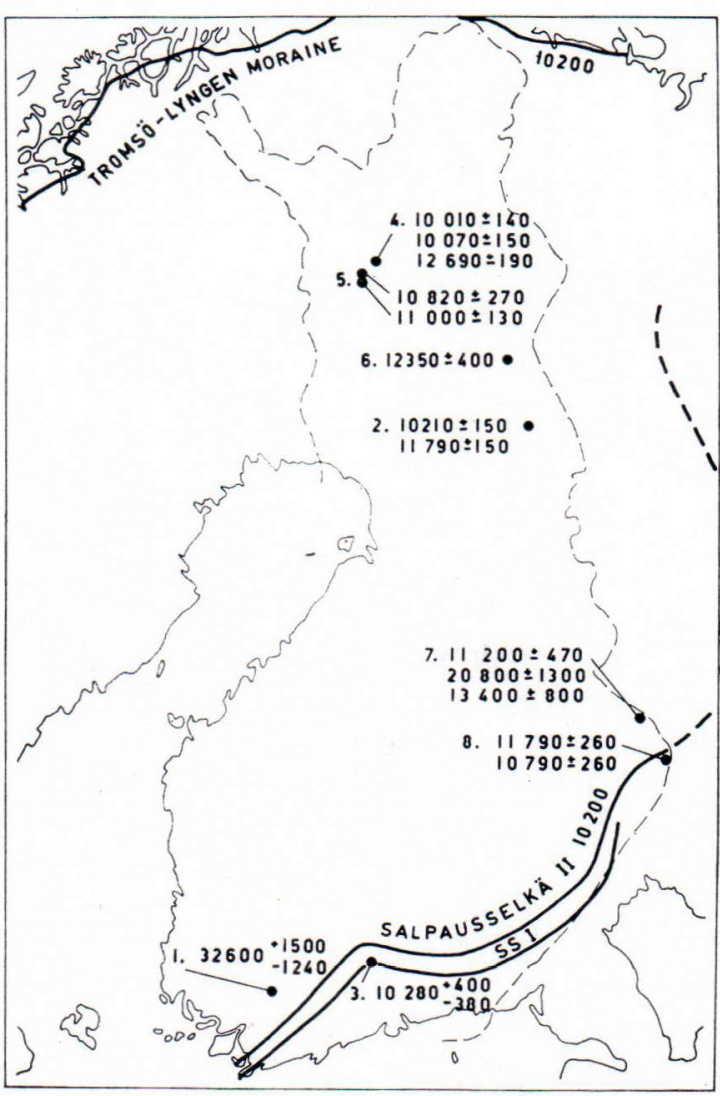

Fig. 2. Map showing the position of the ice margin c. 10200 B.P. and sites with radiocarbon dates which are too old, listed in Fig. 1.

(Andersen 1968), a date corresponding to the final phase of the formation of Salpausselkä II in Finland.

Fig. 3, which lists the sites in Fig. 2, shows the stratigraphy of the sites and the radiocarbon dates with comments on errors affecting the dates. At Somero, Site 1, the c. $30 \mathrm{~m}$ thick early Flandrian clays contained redeposited Eemian pollen (Donner and Gardemeister 1971) and the radiocarbon date of $32600+1500$ (Hel-209, Donner and Jungner 1973) confirmed that the clay contains Eemian organic material. To get an age of 30000 years the clay, which was deposited about 10000 years ago, has to contain about $90 \%$ interglacial material, a likely amount taking into account the strong influence of Eemian pollen on the pollen composition. The dates from the lake muds at Site 2, Säynäjälampi in north-east Finland, studied by Vasari (1963), were shown to have been affected by the hardwater error. This was demonstrated by measurements of the activity of recent Potamogeton species and mud in the lake, the effect making the dates $1000-3000$ years too old (Donner, Jungner and Vasari 1971). At Site 3, Varrassuo near Lahti, from which a number of radiocarbon measurements have earlier been made (Donner 1967), a sample from the underlying silt gave an age of $10280+400$ (U-2431), and the insoluble fraction of the same sample an age of

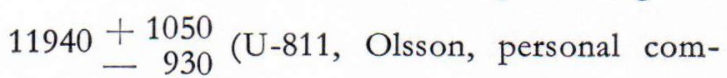
munication). No measurement of the lowermost peat has given a date exceeding 9000 years (Donner 1967). There is no indication of redeposited organic material in the silt, but the presence of graphite could be demonstrated. Graphite, which is present in the Precambrian rocks of Finland, thus influenced the date of the sample with silt. The influence is similar to that in the basal samples from mires in Jämtland, Central Sweden, where ages about 1500 years too old were obtained because of the samples being contaminated with graphite (Lundqvist 1973, p. 166-167).

In the three first sites the errors in the dating have been directly demonstrated and from Fig. 3 it can be seen that the influence of redeposited interglacial organic material is the greatest, the hard-water effect and the influence of graphite having a smaller influence. All of them, however, are serious sources of error when conclusions are drawn about the age of the deglaciation. The results from sites $1-3$ can be used to explain the old dates from the other sites listed in Fig. 3. At Site 4 two of the three radiocarbon dates are from calcareous mud (Salmi 1965). The comparatively old dates are thus at this site most likely caused by the hard-water effect, 
I. SOMERO

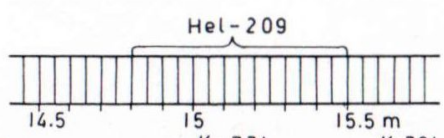

2. SÄYNÄJÄLAMPI, KUUSAMO

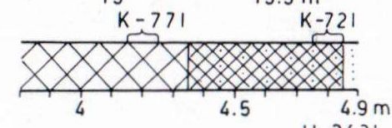

3. VARRASSUO, LAHTI

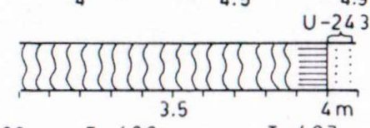

4. MUSIALAMPI, KIITILÄ $T-409 \quad T-408$ $1-407$

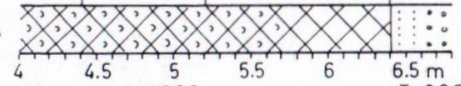

5. PARVAVUOMA, SODANKYLÄ A

B

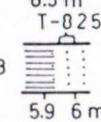

6. AAPALAMPI, SALLA

7. PAPPILANLAMPI, PIELISJÄRVI

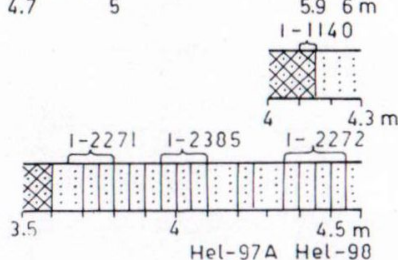

8. SUURI JOUTENLAMPI, ILOMANTSI

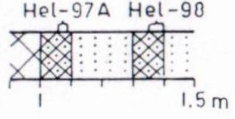

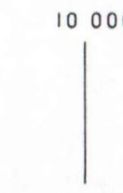

$10210: 150 \quad 11790 \div 150$

1

$10280 \div 40011940+1050$

$$
\underset{-2631 \rightarrow U-811}{\square}
$$

$U-2431 \rightarrow U-81$

$10010 \div 140$

$T-409 \quad 12690=190$

$T-408$ T-407

$10070: 150$

$1-1666 \cdot 10820 \pm 270$

$T-825 \div 11000=130$

$12350 \div 400$

.

$1000=470 \quad 13400: 800$

$\mid \begin{gathered}1-2271 \\ 1-2272\end{gathered}$

Hel-97A $11720 \div 390$

$\mathrm{Hel}-98$ 10 $790: 260$
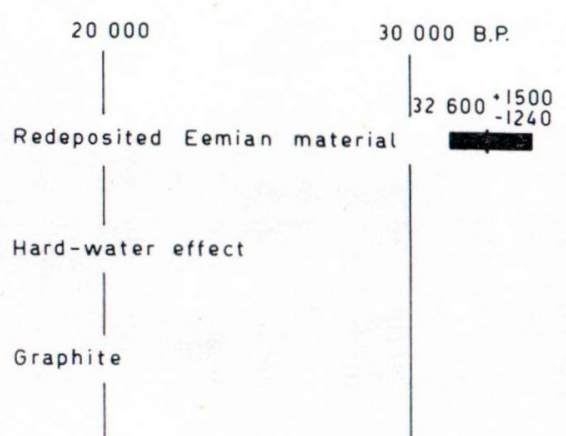

Hard-water effect (calcareous mud)

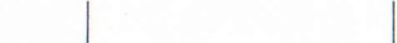

Redeposited organic material (small amount of redeposited pollen)

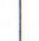

Redeposited organic material (redeposited pollen)

$20800 \div 1300$ Redeposited organic

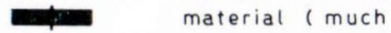

$1-2385$

redeposited pollen

SYMBOLS

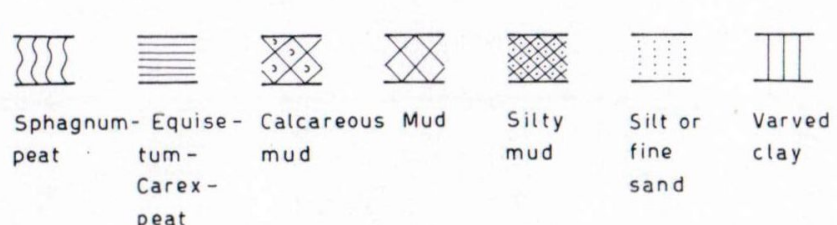

Fig. 3. Stratigraphy of sites with radiocarbon dates which are too old (site numbers same as in Fig. 2) and explanation of errors affecting dates shown. References to sites in the text. 
being of the same order of magnitude as at Site 2. At Parmavuoma, Site 5, the two dates are from the basal layers of two separate profiles, A and B (Lappalainen 1970). Small amounts of redeposited pollen indicate that the main cause for the dates being older than dates from similar layers in northern Finland is the presence of redeposited interglacial material, possibly of interstadial material from the time of the Weichselian Peräpohjola Interstadial, from which peats have been found in Lapland (Korpela 1969). At Site 6 there is clearly an influence of redeposited material, as seen from the pollen content of the basal layers (Sorsa 1965), but the hardwater effect may also have influenced the date of the mud. At Site 7 the three dates given in Fig. 3 are from varved clays with sand layers containing organic material (Tolonen 1967). The oldest date of c. 20000 years is between two younger dates. The pollen diagram shows that the minerogenic layers contain much redeposited pollen, and it is most likely that the dates at this site are too old foremost because of redeposited interglacial organic material, as at Site 1. Sites 5, 6 and 7 were thus probably all influenced by redeposited material, the oldest radiocarbon dates being obtained from sediments with the strongest influence of redeposited material, Site 7 . The reason for the dates at Site 8 (Hyvärinen 1971) being too old can not be determined with certainty. The two dates are in the wrong order and there is some indication of redeposition. The nature of the sediment, rich in minerogenic material, suggests that redeposited organic material at least was partly the cause for the dates being too old but the sediments may also contain graphite, as pointed out by Hyvärinen.

From the discussion above it can be seen that redeposited organic material is mainly responsible for radiocarbon dates being too old in some basal sediments of mires and lakes in Finland, but that an influence of the hard-water effect and of graphite has also been detected. If all these demonstrated errors in radiocarbon dating are taken into account, the dating of the deglaciation in Finland is likely to be that shown in Fig. 1 , which is based on the varve chronology and supported by the study of the vegetational history dated by radiocarbon dates.

\section{REFERENCES}

Andersen, B. G. (1968) Glacial Geology of Western Troms, North Norway. Norges Geol. Unders. 256. $160 \mathrm{p}$.

Donner, J. J. (1967) Late-glacial and early Post-glacial pollen stratigraphy of southern and eastern Finland. Commentat. Biol. 29 (9). 24 p.

- (1971) Towards a stratigraphical division of the Finnish Quaternary. Commentat. Physico-Math. 41: $281-305$.

- and Gardemeister, R. (1971) Redeposited Eemian marine clay in Somero, south-western Finland. Bull. Geol. Soc. Finland 43: 73-88.

- and Jungner, H. (1973) The effect of re-deposited organic material on radiocarbon measurements of clay samples from Somero, south-western Finland. Geol. Fören. Stockholm. Förh. 95 (2): 267-268.

- , Jungner, H. and VASAri, Y. (1971) The hard-water effect on radiocarbon measurements of samples from Säynäjälampi, north-east Finland. Commentat. Physico-Math. 41: 307-310.
Fromm, E. (1970) An estimation of errors in the Swedish varve chronology, pp. 163-172. (in: Radiocarbon Variations and Absolute Chronology, ed. by I. Ohlsson). Nobel Symposium 12, Almqvist \& Wicksell, Stockholm.

Hyvärinen, H. (1971) Two Late Weichselian stratigraphical sites from the eastern foreland of the Salpausselkäs in Finland. Commentat. Biol. 40. 12 p.

- (1972) Flandrian regional pollen assemblage zones in eastern Finland. Commentat. Biol. 59. 25 p.

- (1973) The deglaciation history of eastern Fennoscandia - recent data from Finland. Boreas 2: 85-102.

Korpela, K. (1969) Die Weichsel-Eiszeit und ihr Interstadial in Peräpohjola (nördliches Nordfinnland) im Licht von submoränen Sedimenten. Ann. Acad. Sci. Fennicae A III, 99. 108 p.

LAppalainen, E. (1970) Über die spätquartäre Entwicklung der Flussufermoore Mittel-Lapplands. Bull. Comm. Géol. Finlande 244. 79 p. 
LuNDQvist, J. (1973) Isavsmältningens förlopp i Jämtlands län (Summary: Deglaciation of the County of Jämtland, Central Sweden). Sveriges Geol. Unders. C $681.187 \mathrm{p}$.

Niemelä, J. (1971) Die quartäre Stratigraphie von Tonablagerungen und der Rückzug des Inlandeises zwischen Helsinki und Hämeenlinna in Südfinnland. Geol. Surv. Finland Bull. 253. 79 p.

Nilsson, E. (1968) Södra Sveriges senkvartära historia (Summary: The Late-Quaternary history of southern Sweden). Kungl. Svenska Vetenskapsakad. Handl., Fjärde Ser. 12 (1): 117 p.

SAlmr, M. (1965) Pediastrum alger i den mikropaleontologiska undersökningen. Norsk. Geol. Tidskrift 45 (1). 156.

Sauramo, M. (1918) Geochronologische Studien über die spätglaziale Zeit in Südfinnland. Fennia 41 (1). $44 \mathrm{p}$.

- (1923) Studies on the Quaternary varve sediments in southern Finland. Fennia 44 (1). 164 p.

Sorsa, P. (1965) Pollenanalytische Untersuchungen zur spätquartären Vegetations- und Klimaentwicklung im östlichen Nordfinnland. Ann. Bot. Fennici 2: 301-413.

Tolonen, K. (1967) Über die Entwicklung der Moore im finnischen Nordkarelien. Ann. Bot. Fennici 4: 219-416.

VASARI, Y. (1963) Studies on the vegetational history of the Kuusamo district (North East Finland) during the Late-quaternary period. II. Radiocarbon datings. Preliminary report. Arch. Soc. »Vanamo» 18 (2): $121-127$.

Manuscript received, February 14, 1974. 